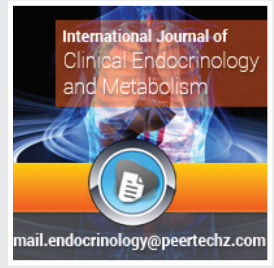

\title{
Clinical Group
}

\section{International Journal of Clinical Endocrinology and Metabolism}

\section{S Li Sun Fui* and P Bonnichon}

Institut Français de Chirurgie Endocrinienne, Ramsay Générale de Santé- Hôpital Privé des Peupliers (HPP), 8 place de l'abbé G. Hénocque 75013 Paris, France

Dates: Received: 06 November, 2017; Accepted: 06 December, 2017; Published: 07 December, 2017

*Corresponding author: S Li Sun Fui, Institute Français de Chirurgie Endocrinienne, Ramsay Générale de SantéHôpital Privé des Peupliers (HPP), 8 place de l'abbé G. Hénocque 75013 Paris, France;

E-mail: lisunfui@gmail.com

https://www.peertechz.com

\section{Case Report}

The profile of primary hyperparathyroidism (PHPT) changed profoundly over the course of the twentieth century. The highly symptomatic forms reported in the 1960s have progressively been replaced by forms with few symptoms and in some cases totally asymptomatic forms. As of 1991, with the increasing frequency of these new forms, several consensus meetings designed to define the criteria for establishing the operability of minimally-symptomatic hyperparathyroidism have been organized [1]. However, the criteria chosen are in some cases deemed too restrictive as they do not take into account general and neuro-psychic symptoms which are frequently associated [2]. Since 1995, with the aim of extending operable criteria several publications including at least 12 prospective and three meta-analyses [3-5], have shown an improvement in the quality of life of patients operated for asymptomatic hyperparathyroidism. Unfortunately these studies which support an approach of operating all patients, have limited practical application. Considered too general, they are rarely appropriate on an individual level. Really the reason for proposing surgical intervention is generally twofold: to reduce the risks (or the negative prognosis) of a disease pathology or to reduce one or more symptoms whose presence and severity hamper the patient's daily quality of life. In the latter case, the improvement of quality of life is an expected consequence of the reduction or elimination of bothersome symptoms but is not the direct motivation behind the surgery. In 1998, based on a study including 5202 post-menopausal women, Ewa Lundgren demonstrated that, relative to the control population, patients suffering from PHPT complained more of fatigue, sleepiness during the day, and feeling weak [6]. For several years now, we consider these symptoms to fall within the context of asthenia, fatigue without a physiological cause (effort or lack of sleep) and which is only partially relieved by rest. So when fatigue is beyond normal physiologic conditions, the more appropriate term to employ is "asthenia". It is associated with $50 \%$ to $98 \%$ of PHPT cases $[7,8$ ], however it is rarely singled out as a symptom and the majority of recent publications on hyperparathyroidism do not directly address asthenia, but include "fatigue" as a criterion for the quality of life. Despite this, the discomfort patients experience is real and represents a true handicap improved by the cure of the PHPT as the tableau 1 shows when asthenia is isolated from these studies. There are at least three possible explanations for this:

- Firstly, the universal nature of fatigue limits its specificity, particularly as semantically it is associated with several and varied qualifiers, which are polymorphic in both French ("affaibli, accablé, fatigué, épuisé, éreinté, exténué, harassé”) and English (fatigue, tiredness, worn out, weakness). This richness of traditional and even slang semantics offers a good understanding the intensity of the fatigue (for example in French "coup de pompe" reflects a slight fatigue, while "éreinté" indicates intense fatigue, and in English "pooped" and "shattered" represent slight and intense fatigue, respectively) with stronger or weaker terminology according to the sensations of the individual. So we think that it is thus logical to ask patients to qualify fatigue using an analogic scale which allows translation of this linguistic richness into a figure. In our experience, all patients, including very elderly patients, were able to evaluate their condition without difficulty.

- Secondly, in contrast to "classic" symptoms of PHPT, there is no known explanation for the physiopathology of fatigue, other than the publication by Soren Deutch which demonstrated a reduction in muscular strength followed by an increase following treatment for PHPT [9] (Table 1).

- Finally, fatigue, i.e., the sensation of bodily reduced strength, is generally considered as a normal physiologic state which most individuals experience are able to evaluate the intensity.

In conclusion, we think that we must now be interested in 
Table 1:

\begin{tabular}{|c|c|c|c|c|c|c|c|}
\hline Authors & Years & Type & $\mathbf{N}$ & $\begin{array}{c}\text { follow up } \\
\text { months }\end{array}$ & $\begin{array}{l}\text { Feel } \\
\text { tired }\end{array}$ & \multicolumn{2}{|c|}{ Worm out } \\
\hline Deutch [9] & 2000 & $\begin{array}{c}\text { scale Ordinal } \\
\text { fatigue }\end{array}$ & 25 & 3 & $<0,05$ & & \\
\hline Greutelaers [10] & 2004 & Pasieka & 71 & 3 & $p<0,05$ & & \\
\hline Quiros [11] & 2003 & SF36 & & $3-24$ & $<0.05$ & $p<0.05$ & \\
\hline Edward [12] & 2006 & SF36 & & $6-12$ & $<0,007$ & $p<0,01$ & \\
\hline Tsukahara [13] & 2007 & Scale : 0,1,2 & 25 & 12 & 0,24 * & & \\
\hline Ramakant [14] & 2011 & $\begin{array}{c}\text { PAS } \\
\text { parameters }\end{array}$ & 27 & 6 & $<0,005$ & & \\
\hline Brito [5] & 2015 & Pasieka & 238 & $6-12$ & $p<0,001$ & & metanalysis \\
\hline Zanocco [15] & 2016 & PROMIS** & & 3 & $8,8^{\star \star \star}$ & & \\
\hline $\begin{array}{l}\text { *8 of } 25 \text { patient } \\
\text { **Patient-Repor } \\
\text { ** *Significatif }\end{array}$ & $\begin{array}{l}\text { have } \\
\text { ted OI } \\
>5\end{array}$ & $\begin{array}{l}\text { ofatigue } \\
\text { omes Measu }\end{array}$ & 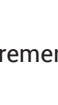 & Inforn & on Sy & & \\
\hline
\end{tabular}

fatigue-symptom i.e. asthenia of HPTH and the best way to do this is to use an analog scale as is done for other symptoms and as we use it in our daily practice.

\section{References}

1. Bilezikian JP, Khan AA, Potts JT Jr (2009) Guidelines for the management of asymptomatic primary hyperparathyroidism: Summary Statement from the Third International Workshop. J Clin Endocrinol Metab 94: 335-339. Link: https://goo.gl/mLDgbf

2. Pasieka JL (2013) The time has come to redefine the classic symptoms of primary hyperparathyroidism: comment on "parathyroidectomy, elevated depression scores, and suicidal ideation in patients with primary hyperparathyroidism". JAMA Surg 148: 115-116. Link: https://goo.gl/K6xojd

3. Cheng SP, Lee JJ, Liu TP, Yang PS, Liu SC, et al. (2015) Quality of Life After Surgery or Surveillance for Asymptomatic Primary Hyperparathyroidism: A Meta-Analysis of Randomized Controlled Trials. Medicine (Baltimore) 94: e931. Link: https://goo.gl/Jzog17

4. Coker L, Rorie K, Cantley L, Kirkland K, Stump D, et al. (2005) Primary hyperparathyroidism, cognition, and health-related quality of life. Ann Surg 242: 642-650. Link: https://goo.gl/CfPBWM

5. Brito K, Edirimanne S, Eslick GD (2015) The extent of improvement of health-related quality of life as assessed by the SF36 and Paseika scales after parathyroidectomy in patients with primary hyperparathyroidism-a systematic review and meta-analysis. Int J Surg13: 245-249. Link: https://goo.gl/8mKcq5

6. Lundgren E, Ljunghall S, Akerström G, Hetta J, Mallmin H, et al. (1998) Case-control study on symptoms and signs of "asymptomatic" primary hyperparathyroidism. Surgery 124: 980-985. Link: https://goo.gl/87gHH2

7. Murray SE, Pathak PR, Pontes DS, Schneider DF, Schaefer SC, et al. (2013) Timing of symptom improvement after parathyroidectomy for primary hyperparathyroidism. Surgery 154: 1463-1469. Link: https://goo.gl/75SNZD

8. Burney R, Jones K, Peterson M, Christy B, Thompson N (1998) Surgical correction of primary hyperparathyroidism improves quality of life Surgery 124: 987-991. Link: https://goo.gl/j5sVQD

9. Deutch SR, Jensen MB, Christiansen PM, Hessov I (2000) Muscular performance and fatigue in primary hyperparathyroidism. World J Surg 2000 24:102-107. Link: https://goo.gl/bnb3jV

10. Greutelaers B, Kullen K, Kollias J, Bochner M, Roberts A, et al. (2004) Pasieka illness questionnaire: its value in primary hyperparathyroidism ANZ J Surg 74: 112-115. Link: https://goo.gl/XBdGa8

11. Quiros R, Alef M, Wilhelm S, Djuricin G, Loviscek K, et al. (2003) Healthrelated quality of life in hyperparathyroidism measurably improves after parathyroidectomy. Surgery 134: 675-683. Link: https://goo.gl/DgUJDd

12. Edwards ME, Rotramel A, Beyer T, Gaffud MJ, Djuricin G (2006) Improvement in the health-related quality-of-life symptoms of hyperparathyroidism is durable on long-term follow-up. Surgery 140: 655-663. Link: https://goo.gl/cys8hz

13. Tsukahara K, Sugitani I, Fujimoto Y, Kawabata K (2008) Surgery did not improve the subjective neuropsychological symptoms of patients with incidentally detected mild primary hyperparathyroidism. Eur Arch Otorhinolaryngol 265: 565-569. Link: https://goo.gl/s4Tmnw

14. Ramakant P, Verma AK, Chand G, Mishra A, Agarwal G, et al. (2011) Salutary effect of parathyroidectomy on neuropsychiatric symptoms in patients with primary hyperparathyroidism: Evaluation using PAS and SF-36v2 scoring systems. J Postgrad Med 57: 96-101. Link: https://goo.gl/egy9g6

15. Zanocco K, Butt Z, Kaltman D, Elaraj D, Cella D, et al. (2015) Improvement in patient-reported physical and mental health after parathyroidectomy for primary hyperparathyroidism. Surgery 158: 837-845. Link: https://goo.gl/8TZsDu

Copyright: @ 2017 Sun Fui SL, et al. This is an open-access article distributed under the terms of the Creative Commons Attribution License, which permits unrestricted use, distribution, and reproduction in any medium, provided the original author and source are credited. 